2013s-43

\title{
Probability and Severity of Recessions
}

Rachidi Kotchoni, Dalibor Stevanovic

Série Scientifique
Scientific Series

Montréal
Novembre 2013/November 2013
(version révisée : juin 2014 - Revised version : June 2014)

(C) 2013 Rachidi Kotchoni, Dalibor Stevanovic. Tous droits réservés. All rights reserved. Reproduction partielle permise avec citation du document source, incluant la notice $\odot$.

Short sections may be quoted without explicit permission, if full credit, including @ notice, is given to the source.

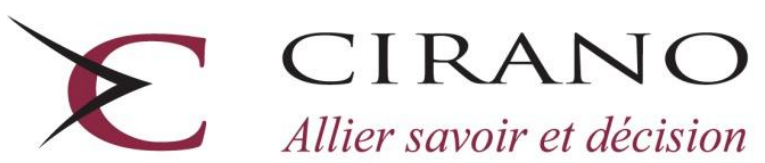

Centre interuniversitaire de recherche en analyse des organisations 